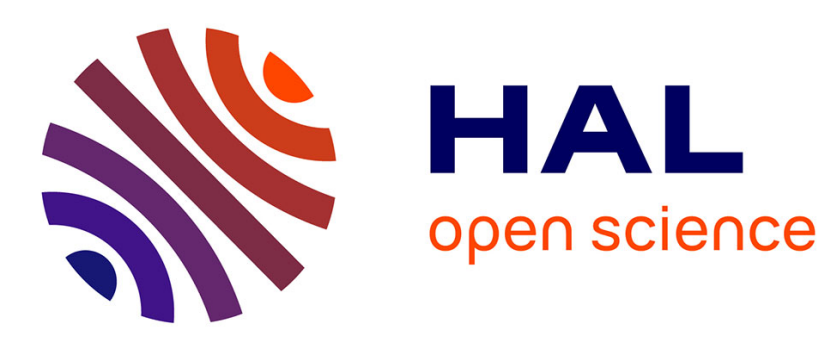

\title{
Characterisation of hepatitis B virus in Turkish blood donors, and the prevalence of the SP1 splice variant.
}

Laura Elizabeth Cox, Onder Arslan, Jean-Pierre Allain

\section{To cite this version:}

Laura Elizabeth Cox, Onder Arslan, Jean-Pierre Allain. Characterisation of hepatitis B virus in Turkish blood donors, and the prevalence of the SP1 splice variant.. Journal of Medical Virology, 2011, 83 (8), pp.1321. 10.1002/jmv.22118 . hal-00652148

\section{HAL Id: hal-00652148 \\ https://hal.science/hal-00652148}

Submitted on 15 Dec 2011

HAL is a multi-disciplinary open access archive for the deposit and dissemination of scientific research documents, whether they are published or not. The documents may come from teaching and research institutions in France or abroad, or from public or private research centers.
L'archive ouverte pluridisciplinaire HAL, est destinée au dépôt et à la diffusion de documents scientifiques de niveau recherche, publiés ou non, émanant des établissements d'enseignement et de recherche français ou étrangers, des laboratoires publics ou privés. 
Characterisation of hepatitis B virus in Turkish blood donors, and the prevalence of the SP1 splice variant.

\begin{tabular}{|r|l|}
\hline Journal: & Journal of Medical Virology \\
\hline Manuscript ID: & JMV-10-2247.R1 \\
\hline Wiley - Manuscript type: & Research Article \\
\hline Date Submitted by the \\
Author: & 01-Apr-2011 \\
\hline Complete List of Authors: & $\begin{array}{l}\text { Cox, Laura; University of Cambridge, Haematology } \\
\text { Arslan, Onder; Ankara University, Haematology } \\
\text { Allain, Jean-Pierre; University of Cambridge, Haematology }\end{array}$ \\
\hline Keywords: & Turkey, HBV, sequencing, splicing \\
\hline \multicolumn{2}{|c}{} \\
\hline
\end{tabular}

SCHOLARONE $^{\text {M }}$ Manuscripts 
1 Characterisation of hepatitis B virus in Turkish blood donors, and the prevalence of the SP1 splice variant.

4 Laura E. Cox $^{1}$

5 Önder Arslan ${ }^{2}$

6 Jean-Pierre Allain ${ }^{1}$

7

$8{ }^{1}$ Division of Transfusion Medicine, Department of Haematology, University of Cambridge,

9 Cambridge Blood Centre, Long Road, Cambridge CB2 OPT, UK. (Institution where work was

10 performed)

$11{ }^{2}$ Ankara University, School of Medicine, Department of Haematology, Blood Bank \& Apheresis

12 Unit, Cebeci, 06590, Ankara, Turkey.

13

14 Correspondence to:

15 Laura Cox: Email: lec48@cam.ac.uk

16 Jean-Pierre Allain: Email: jpa1000@cam.ac.uk

17 Division of Transfusion Medicine, Department of Haematology, University of Cambridge,

18 Cambridge Blood Centre, Long Road, Cambridge CB2 OPT, UK.

19

20 Running title: HBV characterisation in Turkish blood donors

21 Key words: Turkey, HBV, sequencing, splicing 


\section{Abstract}

24 Hepatitis B is a disease of the liver that can manifest acutely, or persist chronically as a result of 25 infection with the hepatitis B virus (HBV). Turkey has a moderate endemicity level of HBV 26 infection, and all data published to date has shown this to be of genotype D, predominantly of 27 subgenotype D1. However the sequences of very few full genomes have been published. The 28 aim of this study was to characterise the molecular profile of hepatitis B virus in asymptomatic,

29 first-time Turkish blood donors. These results confirm that genotype D, subgenotype D1 is the 30 most prevalent HBV strain in Turkey, accounting for $94 \%$ of cases. Subgenotypes D2 and D3

31 were present as minority strains ( $4 \%$ and $2 \%$, respectively). A singly-spliced HBV variant that is

32 capable of forming defective HBV particles and has been associated with apoptosis and

33 activation of T-cell responses was also detected in $52.5 \%$ of samples screened, co-circulating

34 with wild type genomes.

35 


\section{Introduction}

Hepatitis B virus (HBV) carrier prevalence in Turkey is reported to be around $4 \%$

38 [Degertekin and Gunes, 2008], which is in line with other Mediterranean and Middle Eastern

39 countries and meets the criteria for intermediate endemicity level. HBV belongs to the family

40 Hepadnaviridae, and has a $3.2 \mathrm{~kb}$ genome that, when encapsidated within the virion, is a relaxed

41 circular DNA molecule that is only partially double-stranded. It was first reported in 1989 that

42 HBV could undergo splicing by the host's machinery in human hepatoma cells transfected with

43 full-length HBV [Su et al., 1989]. This $2 \mathrm{~kb}$ variant is commonly termed SP1, and contains a 1223

44 nucleotide deletion beginning at the last codon of the core gene and spanning through to the

45 middle of the $\mathrm{S}$ gene. To date, this splice variant has been identified in chronic hepatitis $\mathrm{B}$

46 patients infected with HBV genotypes $A$ and $D$, and an additional 10 splice variants have been

47 identified in patients infected with genotypes A, B and D [Gunther et al., 1997].

48 HBV is divided into eight well-documented genotypes $(\mathrm{A}-\mathrm{H})$, some of which are further

49 divided into two or more sub-genotypes [Kay and Zoulim, 2007]. Recently, two putative new

50 genotypes, I and J, have been reported [Tatematsu et al., 2009; Tran et al., 2008]. Genotype D is

51 predominant in the Mediterranean basin, and is also frequently found in populations from

52 Europe, Africa and Asia. Of the HBV genotypes, this is the least defined geographically, which

53 may be a result of diverging earlier than the other genotypes [Norder et al., 2004]. The majority

54 of the current data on HBV in Turkey has come from patients with clinical Hepatitis B, with few

55 full genome sequences published. Sequencing of full genomes and the $\mathrm{S}$ gene from patients with

56 chronic HBV infection identified only genotype D in Turkish samples, and where subgenotyping

57 was documented, D1 was the most prevalent subgenotype, with a minority of subgenotype D2

58 strains present [Bozdayi et al., 2005; Sayiner et al., 2008; Serin et al., 2005; Sertoz et al., 2008].

59 The aim of this study was to characterise HBV strains obtained from HBsAg-positive plasma 
60 samples from asymptomatic, first-time, replacement blood donors collected in Ankara, Turkey,

61 using serological and molecular techniques.

62

63 Materials \& Methods

64 HBsAg-positive plasma samples were collected during 3 separate periods in 2004, 2005

65 and 2006, with a total collection period of 13 months. Samples were heat-inactivated at $60^{\circ} \mathrm{C}$ for

6630 min prior to shipping on dry ice, and upon arrival in the UK were stored at $-80^{\circ} \mathrm{C}$ until ready

67 to use. Viral DNA was extracted and quantified as described previously [Allain et al., 2003;

68 Garmiri et al., 2009]. To generate sequence for the entire HBV genome from 50 samples, the

69 Expand High Fidelity PCR system (Roche) was used for two nested PCR assays. Firstly, a nearly

70 full-length fragment of approximately $3000 \mathrm{bp}$, minus a $50 \mathrm{bp}$ precore section was amplified as

71 previously described [Zahn et al., 2008]. A second 300bp fragment including the basic core

72 promoter/precore (BCP/PC) 50bp gap was produced to complete the full genome [Candotti et

73 al., 2006]. PCR products were purified using the EZNA cycle pure kit (Omega; Crawley, UK).

74 A semi-nested PCR was used to screen for the SP1 variant, using newly designed primers

75 located in the core and S genes. SP1_core (5'-GTCGCAGAAGATCTCAATCTCGGG-3'; position

76 2421-2444) was used as the sense primer in both first and second round PCR; SP1_R1 (5'-

77 ATACAAAgGCATtAATGCAggGTA-3'; position 1065-1042) and SP1_R2 (5'-

78 TGTGTAAATGGAGCGGCAAAGCC-3'; position 1012-1034) were used as the anti-sense primers in

79 first and second round PCR, respectively. Using the Roche Expand High Fidelity system, a 50 $\mu \mathrm{L}$

80 reaction mixture contained: 1 X PCR buffer II (including $\mathrm{MgCl}_{2}$; final concentration $2.5 \mathrm{mM}$ ), 0.8

$81 \mathrm{~mm}$ dNTPs, $0.3 \mu \mathrm{M}$ each primer, and $5.25 \mathrm{U}$ HiFi. For samples with a viral load of $\times 10^{8} \mathrm{IU} \mathrm{ml}^{-1}$ or

82 above, $3 \mu$ l of viral DNA was used as first-round template; $5 \mu l$ was used for samples with viral

83 loads of $x 10^{4}-\times 10^{7} \mathrm{IU} \mathrm{ml^{-1 }}$ and $10 \mu \mathrm{L}$ for samples $\times 10^{3} \mathrm{IU} \mathrm{ml}^{-1}$ or below. Six microlitres of the 
84 first-round reaction was loaded into the second-round PCR. An identical touchdown cycling 85 programme was used for both rounds, and consisted of: an initial denaturation step at $94^{\circ} \mathrm{C}$ for 865 minutes, followed by 10 cycles of $94^{\circ} \mathrm{C} / 40 \mathrm{~s} ; 65^{\circ} \mathrm{C} / 45$ s (reduced by $1^{\circ} \mathrm{C}$ each cycle); $72^{\circ} \mathrm{C} / 1$

$87 \mathrm{~min}$, and a following 30 cycles of $94^{\circ} \mathrm{C} / 40 \mathrm{~s} ; 55^{\circ} \mathrm{C} / 45 \mathrm{~s} ; 72^{\circ} \mathrm{C} / 1 \mathrm{~min}$. A final extension step was 88 performed at $72^{\circ} \mathrm{C}$ for 10 minutes. In the presence of full-length HBV DNA (3.2kb) a $1.8 \mathrm{~kb}$

89 product is amplified, in comparison to a 580bp product for the SP1 variant, visualised using 90 agarose gel electrophoresis.

91 Sequences with interesting deletions or insertions were examined further by fresh full 92 genome or BCP/PC PCR reactions. Following addition of a $3^{\prime}$ single adenosine overhang to the 93 PCR product, amplicons were ligated into either the $\mathrm{pCR} 2.1 \mathrm{TOPO}^{\circledR} \mathrm{TA}$ vector $(\mathrm{BCP} / \mathrm{PC})$ or the

$94 \mathrm{TOPO}^{\circledR} \mathrm{XL}$ vector (Invitrogen; Paisley, UK) as per the manufacturer's instructions. Following 95 transformation of chemically competent E. coli cells, plasmid DNA was isolated using a QIAprep 96 spin miniprep kit (Qiagen), and a minimum of 10 clones were sequenced.

97 Sequencing and phylogenetics analysis was performed using Seqman, SeqBuilder 98 (DNASTAR) and MacVector software. PAUP* version 4.0 beta 10 was used to calculate genomic 99 distances. Microsoft Excel and Prism (version 4) were used for analysis of HBV DNA and HBsAg 100 load.

101 Antibodies against HBcAg (anti-HBc) and HBsAg (anti-HBs) were tested by ELISA with a 102 Monolisa ${ }^{\circledR}$ anti-HBc PLUS kit (Bio-Rad; Hemel Hempstead, UK) and a Monolisa ${ }^{\circledR}$ anti-HBs PLUS kit 103 (Bio-Rad), respectively.

\section{Results}

106 Over the collection period samples were taken from 20,960 first-time, replacement 107 blood donors (18,898 male: 2,062 female). Routine screening identified 200 samples as positive 
108 for HBsAg (187 male: 13 female), giving a prevalence of $1 \%$ for males and $0.6 \%$ for females.

109 Plasma was obtained for 199 HBsAg positive samples, and quantification of HBV DNA load by Q-

110 PCR was successful in $176(88.4 \%)$ of these samples. The median viral load was $1.19 \times 10^{3} \mathrm{IU} \mathrm{ml}^{-1}$

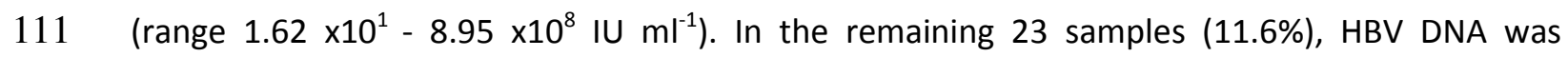

112 undetected by Q-PCR. However amplification of the BCP/PC region was achieved by nested-PCR

113 in one of the 23 samples, meaning detection of HBV DNA was possible for a total of 177/199

114 samples (89\%).

115 Complete genomic sequences were obtained for 50 samples (GenBank Accession

116 numbers: JF754586-JF754635), from 57 randomly selected samples in which this was attempted.

117 Phylogenetic analysis identified all strains as belonging to HBV genotype D; 47 clustered as

118 subgenotype D1 (94\%), 2 as subgenotype D2 (4\%), and 1 as subgenotype D3 (2\%). Sequence

119 analysis of the S gene revealed the predominant serotype to be ayw2 $(n=41), 5$ strains specified

120 ayw3 and 1 strain was ayw4. An additional strain belonged to serotype adw, but could not be

121 classified further, and serotype determination was not possible in one strain due to a deletion in

122 this region (Table I).

123

$124 \mathrm{PreC} / \mathrm{C}$

125 One sample contained a deletion of 37 nucleotides, resulting in a frameshift mutation

126 and premature protein truncation. In another strain, insertion of two adenine nucleotides in the

127 precore region caused a frameshift mutation, which is predicted to result in the inclusion of 31

128 amino acids in the precore protein, whilst leaving the core protein unaffected. Cloning of the

$129 \mathrm{BCP} / \mathrm{PC}$ for this strain identified the double adenine insertion in all 10 clones sequenced. Serum

130 testing of these two samples identified the presence of anti-HBc. Another sample contained a

131 single adenine insertion within the core region, introducing a premature stop codon and protein 
132 truncation. Serum was not available for anti-HBc testing of this sample. Seven samples (14\%)

133 contained mutations that abolished the precore initiation codon. The G1896A mutation, which

134 introduces a premature stop codon and abolishes precore protein and HBeAg synthesis, was

135 present in 33 strains (66\%).

136

137 Pre-S/S

138 Mutations disrupting the initiation codon of Pre-S2 were identified in 3 samples (6\%).

139 Five samples contained deletions in the Pre-S/S transcript, ranging in size from 6 to 51

140 nucleotides. These were present throughout the three ORFs. Three samples contained nonsense

141 mutations that are predicted to result in premature truncation of the protein. One further

142 sample contained a 66 nucleotide deletion spanning the Pre-S1/Pre-S2 boundary, in addition to

143 a nonsense mutation leading to premature truncation of the S protein at amino acid residue 69.

144 Testing for the presence of anti-HBs in the serum from which this strain was obtained was

145 negative. Cloning of this sample identified the presence of wild-type species, in addition to a

146 much smaller product with a 1223 nucleotide deletion (positions 2449-489), predicted to result

147 from splicing of viral mRNA. This deletion started at the final codon of the core gene and

148 extended into the middle of the $\mathrm{S}$ gene.

149 The mean overall amino acid divergence within the Pre-S/S region was $2.7 \%$ (range 0-

150 6.9\%). The major hydrophilic region (positions 100-169) was more variable, with a mean amino

151 acid substitution rate of $5.3 \%$ (range $0-20 \%$ ). No substitutions associated with vaccine-escape

152 mutants were identified in this cohort.

153

$154 \quad X$ gene 
155 No deletions were present within the $X$ transcript in any samples. However, one strain

156 contained a 6 nucleotide insertion, leading to the inclusion of two additional amino acid residues

157 (glycine and methionine) in the $X$ protein, inserted between wild-type residues 79 and 80 . The

158 basal core promoter (BCP) variants, A1762T and G1764A were present as a dual mutation in 10

159 strains, with an additional 6 samples carrying G1764A as a single change.

160

$161 \quad$ Pol

162 Six strains carrying deletions in the polymerase gene ranging between 6-66 nucleotides

163 were identified; these were all located in the spacer domain of the protein. There were no

164 disruptions to the highly conserved YMDD motif in any of the 50 strains sequenced. One further

165 sample had a 6 nucleotide insertion within the RNase $\mathrm{H}$ domain of the protein.

166

167 SP1 screening

168 Screening for the presence of the SP1 variant was successful in 40/43 samples in which

169 this was attempted (Figure 1). A full genome sequence was available for 27 of the 40

170 successfully amplified samples. The SP1 variant was present in 10/10 (100\%) samples with viral

171 loads $\geq 10^{6}$, in $8 / 18$ (44\%) samples with viral loads of $\geq 10^{4}-<10^{6}$, and in $3 / 12(25 \%)$ of samples

172 with viral loads $<10^{4}$.

173

174 Discussion

175 Analysis of 50 full HBV genotypes extracted from asymptomatic Turkish blood donors

176 selected at random supports previous findings that the most prevalent HBV strain in this country

177 is subgenotype D1 and serotype ayw2 [Bozdayi et al., 2005; Sertoz et al., 2008]. 
178 In previously published complete HBV genomes from chronic Hepatitis B patients from

179 Turkey, the G1896A variant was identified in $18 \%$ of samples, and these patients were HBeAg 180 negative [Bozdayi et al., 2005]. In this cohort from healthy volunteer donors, the G1896A 181 precore stop variant was identified in $66 \%$ of samples. This is in keeping with data that shows a 182 high prevalence of the G1896A mutation in samples from Mediterranean populations [Funk et 183 al., 2002]. G1896A has previously been documented to be present in 15\% of HBeAg-positive 184 Turkish patients, compared to $85 \%$ of HBeAg-negative patients [Bozdayi et al., 1999; Bozdayi et 185 al., 2005]. This mutation is of interest as it results in the prevention of HBeAg synthesis, and 186 seroconversion of HBeAg to anti-HBe is correlated with a decline in viral load [Tedder et al., 187 2002]. The core promoter dual mutations (A1762T, G1764A) were identified previously in 3/11 188 chronic-HBV infected patients, one of whom was HBeAg positive [Bozdayi et al., 2005], and was 189 identified in $20 \%$ of the strains sequenced in this study. The double mutation has been 190 implicated with a reduction in the generation of precore mRNA and HBeAg production, and is 191 more prevalent in patients with advanced liver disease [Poustchi et al., 2008]. Given the 192 relatively high frequency of these mutations in this study population, and their clinical 193 implications, it may be of use to sequence the viral genome in subjects testing positive for HBV194 infection in Turkey.

195 This is the first time that screening of the SP1 variant has been conducted in 196 asymptomatic blood donors. The data demonstrated that the SP1 variant was present in more 197 than half of the samples screened (21/40), and was ubiquitous in samples with viral loads $\geq 10^{6}$. 198 However, that SP1 is detected at a much lower frequency in samples with low viral loads (3/10 $199 \mathrm{VL}<10^{4} \mathrm{IU} / \mathrm{mL}$ ) may not be directly linked to viral load, but may be a matter of the ratio at 200 which the transcripts are present and the ability of the PCR to detect very low levels of the 201 spliced variant. Previous studies have examined the prevalence in symptomatic HBV-infected 
202 patients, and have correlated its presence with chronic infection and hepatocellular carcinoma

203 [Lin et al., 2002]. The association between prevalence of the HBV splice variant and severity of

204 liver disease is not yet elucidated; one study reported an association between a high proportion

205 of spliced HBV: wild-type HBV in patients with more severe liver necroinflammation [Soussan et

206 al., 2008], whereas a different study found no association between spliced HBV prevalence and

207 disease status [Preiss et al., 2008]. Decreased levels of SP1 have been observed in patients with

208 a lamivudine-resistant HBV strain, suggesting that antiviral therapy disrupts the balance

209 between circulating HBV splice variants and full-length HBV genomes [Preiss et al., 2008].

210 In addition, a novel 10.4kDa protein (HBV splice-generated protein; HBSP) arose from

211 the fusion of a section of the polymerase and a new ORF created downstream of the splicing

212 event [Soussan et al., 2000]. Detection by western blot analysis has revealed the presence of

213 this protein in $46 \%$ of serum samples from chronic HBV carriers, as opposed to $<1 \%$ of healthy

214 HBV-negative controls [Soussan et al., 2003]. Functionally, this protein has been demonstrated

215 in vitro to increase hepatocyte apoptosis [Soussan et al., 2000], and in humans and transgenic

216 mice to induce a T-cell response [Mancini-Bourgine et al., 2007].

217

218 Acknowledgements

219 The authors would like to thank Mrs Yeşim Özer and the staff of the Blood Bank \& Apheresis

220 Unit, Ankara, Turkey who participated in the collection and screening of blood donor samples, in

221 addition to Dr B.H.M. Meldal and Dr I.H.A. Barnes for their contribution to DNA extraction and

222 quantification. This study was supported by grant BS05/2 from the National Health Service Blood

223 and Transplant.

224 
References:

226

Allain JP, Candotti D, Soldan K, Sarkodie F, Phelps B, Giachetti C, Shyamala V, Yeboah F, Anokwa M, Owusu-Ofori S, Opare-Sem O. 2003. The risk of hepatitis B virus infection by transfusion in Kumasi, Ghana. Blood 101(6):2419-2425.

Bozdayi AM, Bozkaya H, Turkyilmaz A, Aslan N, Verdi H, Kence A, Uzunalimoglu O. 1999. Polymorphism of precore region of hepatitis B virus DNA among patients with chronic HBV infection in Turkey. Infection 27(6):357-360.

Bozdayi G, Turkyilmaz AR, Idilman R, Karatayli E, Rota S, Yurdaydin C, Bozdayi AM. 2005. Complete genome sequence and phylogenetic analysis of hepatitis B virus isolated from Turkish patients with chronic HBV infection. J Med Virol 76(4):476-481.

Candotti D, Opare-Sem O, Rezvan H, Sarkodie F, Allain JP. 2006. Molecular and serological characterization of hepatitis B virus in deferred Ghanaian blood donors with and without elevated alanine aminotransferase. J Viral Hepat 13(11):715-724.

Degertekin H, Gunes G. 2008. Horizontal transmission of hepatitis B virus in Turkey. Public Health 122(12):1315-1317.

Funk ML, Rosenberg DM, Lok AS. 2002. World-wide epidemiology of HBeAg-negative chronic hepatitis $\mathrm{B}$ and associated precore and core promoter variants. J Viral Hepat 9(1):52-61.

Garmiri P, Loua A, Haba N, Candotti D, Allain JP. 2009. Deletions and recombinations in the core region of hepatitis $\mathrm{B}$ virus genotype $\mathrm{E}$ strains from asymptomatic blood donors in Guinea, west Africa. J Gen Virol 90(Pt 10):2442-2451.

Gunther S, Sommer G, Iwanska A, Will H. 1997. Heterogeneity and common features of defective hepatitis $B$ virus genomes derived from spliced pregenomic RNA. Virology 238(2):363-371.

Kay A, Zoulim F. 2007. Hepatitis B virus genetic variability and evolution. Virus Res 127(2):164-176.

Lin X, Wen Y, Wan D, Qian G, Gu J. 2002. Structural and functional analysis of $2.2 \mathrm{~kb}$ spliced variant of hepatitis B virus genomes isolated from liver tissues from hepatocellular carcinoma patients. Zhonghua Shi Yan He Lin Chuang Bing Du Xue Za Zhi 16(1):11-15.

Mancini-Bourgine M, Bayard F, Soussan P, Deng Q, Lone YC, Kremsdorf D, Michel ML. 2007. Hepatitis B virus splice-generated protein induces T-cell responses in HLA-transgenic mice and hepatitis B virus-infected patients. J Virol 81(10):49634972.

Norder H, Courouce AM, Coursaget P, Echevarria JM, Lee SD, Mushahwar IK, Robertson BH, Locarnini S, Magnius LO. 2004. Genetic diversity of hepatitis B virus strains derived worldwide: genotypes, subgenotypes, and HBsAg subtypes. Intervirology 47(6):289-309.

Poustchi H, Mohamadkhani A, Bowden S, Montazeri G, Ayres A, Revill P, Farrell GC, Locarnini S, George J, Malekzadeh R. 2008. Clinical significance of precore and 
core promoter mutations in genotype D hepatitis B-related chronic liver disease. $\mathrm{J}$ Viral Hepat 15(10):753-760.

Preiss S, Littlejohn M, Angus P, Thompson A, Desmond P, Lewin SR, Sasadeusz J, Matthews G, Dore GJ, Shaw T, Sozzi V, Yuen L, Lau G, Ayres A, Thio C, Avihingsanon A, Ruxrungtham K, Locarnini S, Revill PA. 2008. Defective hepatitis B virus DNA is not associated with disease status but is reduced by polymerase mutations associated with drug resistance. Hepatology 48(3):741-749.

Sayiner AA, Ozcan A, Sengonul A. 2008. Naturally occurring MHR variants in Turkish patients infected with hepatitis B virus. J Med Virol 80(3):405-410.

Serin MS, Akkiz H, Abayli B, Oksuz M, Aslan G, Emekdas G. 2005. Genotyping of hepatitis B virus isolated from chronic hepatitis B patients in the south of Turkey by DNA cycle-sequencing method. Diagn Microbiol Infect Dis 53(1):57-60.

Sertoz RY, Erensoy S, Pas S, Ozacar T, Niesters H. 2008. Restriction fragment length polymorphism analysis and direct sequencing for determination of $\mathrm{HBV}$ genotypes in a Turkish population. New Microbiol 31(2):189-194.

Soussan P, Garreau F, Zylberberg H, Ferray C, Brechot C, Kremsdorf D. 2000. In vivo expression of a new hepatitis B virus protein encoded by a spliced RNA. J Clin Invest 105(1):55-60.

Soussan P, Pol J, Garreau F, Schneider V, Le Pendeven C, Nalpas B, Lacombe K, Bonnard P, Pol S, Kremsdorf D. 2008. Expression of defective hepatitis B virus particles derived from singly spliced RNA is related to liver disease. $J$ Infect Dis 198(2):218-225.

Soussan P, Tuveri R, Nalpas B, Garreau F, Zavala F, Masson A, Pol S, Brechot C, Kremsdorf D. 2003. The expression of hepatitis B spliced protein (HBSP) encoded by a spliced hepatitis B virus RNA is associated with viral replication and liver fibrosis. J Hepatol 38(3):343-348.

Su TS, Lai CJ, Huang JL, Lin LH, Yauk YK, Chang CM, Lo SJ, Han SH. 1989. Hepatitis B virus transcript produced by RNA splicing. J Virol 63(9):4011-4018.

Tatematsu K, Tanaka Y, Kurbanov F, Sugauchi F, Mano S, Maeshiro T, Nakayoshi T, Wakuta M, Miyakawa Y, Mizokami M. 2009. A genetic variant of hepatitis B virus divergent from known human and ape genotypes isolated from a Japanese patient and provisionally assigned to new genotype J. J Virol 83(20):1053810547.

Tedder RS, Ijaz S, Gilbert N, Barbara JA, Corden SA, Gilson RJ, Boxall EH. 2002. Evidence for a dynamic host-parasite relationship in e-negative hepatitis $\mathrm{B}$ carriers. J Med Virol 68(4):505-512.

Tran TT, Trinh TN, Abe K. 2008. New complex recombinant genotype of hepatitis B virus identified in Vietnam. J Virol 82(11):5657-5663.

Zahn A, Li C, Danso K, Candotti D, Owusu-Ofori S, Temple J, Allain JP. 2008. Molecular characterization of occult hepatitis B virus in genotype E-infected subjects. J Gen Virol 89(Pt 2):409-418. 


\section{Legends:}

313 Table I: Molecular and serological characteristics of HBV strains from Turkish blood donors.

314 Summary of the features identified in the HBV strains sequenced, including deletions, 315 truncations and insertions in the four ORFs, and viral load and SP1 distribution. (HBV: hepatitis B 316 virus)

318 Figure 1: Representative gel of SP1 screening. Amplification of full-length sequence results in a 319 1802bp product, whereas spliced HBV DNA, which contains a 1223 nucleotide deletion,

320 generates a 579bp product. Depending on the ratios present, both products may be amplified or 321 alternatively only one amplicon is generated. Sample 1: TK89; Sample 2: TK88 (JF754601);

322 Sample 3: TK129 (JF754618); Sample 4: TK32; Sample 5: TK28 (JF754624); Sample 6: TK74;

323 Sample 7: TK171 (JF754623); Sample 8: TK178; Sample 9: TK63 (JF754608); Sample 10: TK38

324 (JF754591); Sample 11: TK70). (Marker: Bioline, Hyperladder I; HBV: hepatitis B virus) 


\section{Table I}

\begin{tabular}{|c|c|c|c|c|c|}
\hline \multirow{2}{*}{$\begin{array}{r}\text { Feature } \\
\text { Genotype }\end{array}$} & \multicolumn{5}{|c|}{$\begin{array}{l}\text { Results } \\
\text { (No. of strains in which feature present/No. }\end{array}$} \\
\hline & D1 (47/50) & D2 (2/50) & D3 (1/50) & & \\
\hline Serotype & $\begin{array}{l}\mathrm{adw} \\
(1 / 50)\end{array}$ & $\begin{array}{l}\text { ayw2 } \\
(41 / 50)\end{array}$ & $\begin{array}{l}\text { ayw3 } \\
(5 / 50)\end{array}$ & $\begin{array}{l}\text { ayw4 } \\
(1 / 50)\end{array}$ & $\begin{array}{c}\text { Unknown } \\
(2 / 50)\end{array}$ \\
\hline X ORF & Deletions $(0 / 50)$ & $\begin{array}{l}\text { Insertions } \\
(1 / 50)(6 b p)\end{array}$ & $\begin{array}{l}\text { Truncations } \\
(0 / 50)\end{array}$ & & \\
\hline Pol ORF & $\begin{array}{l}\text { Deletions }(6 / 50) \\
(6-66 \mathrm{bp})\end{array}$ & $\begin{array}{l}\text { Insertions } \\
(1 / 50)(6 b p)\end{array}$ & $\begin{array}{l}\text { Truncations } \\
(0 / 50)\end{array}$ & & \\
\hline Pre-S/S ORF & $\begin{array}{l}\text { Deletions }(6 / 50) \\
(6-66 \mathrm{bp})\end{array}$ & $\begin{array}{l}\text { Insertions } \\
(0 / 50)\end{array}$ & $\begin{array}{l}\text { Truncations } \\
(4 / 50) \\
(12-474 b p)\end{array}$ & & \\
\hline Pre-C/C ORF & $\begin{array}{l}\text { Deletions (1/50) } \\
(37 \mathrm{bp})\end{array}$ & $\begin{array}{l}\text { Insertions } \\
(2 / 50) \\
(1-2 b p)\end{array}$ & $\begin{array}{l}\text { Truncations } \\
(2 / 50)(369- \\
417 \mathrm{bp})\end{array}$ & $\begin{array}{l}\text { G1896A } \\
(33 / 50)\end{array}$ & \\
\hline $\begin{array}{l}\text { Viral load (VL) } \\
(\mathrm{IU} / \mathrm{mL})\end{array}$ & $\begin{array}{l}\text { Undetectable } \\
(23 / 199)\end{array}$ & $\begin{array}{l}<100 \\
(26 / 199)\end{array}$ & $\begin{array}{l}1 \times 10^{2}-9 \times 10^{3} \\
(120 / 199)\end{array}$ & $\begin{array}{l}1 \times 10^{4}- \\
9 \times 10^{6} \\
(22 / 199)\end{array}$ & $\begin{array}{l}>1 \times 10^{7} \\
(8 / 199)\end{array}$ \\
\hline $\begin{array}{l}\text { Splice variant } \\
\text { (SP1) prevalence }\end{array}$ & $\begin{array}{l}\text { VL }<\times 10^{4} \\
(3 / 12)\end{array}$ & $\begin{array}{l}\mathrm{VL} \geq \times 10^{4}- \\
<\times 10^{6}(8 / 18)\end{array}$ & $\begin{array}{l}\mathrm{VL}>\times 10^{6} \\
(10 / 10)\end{array}$ & & \\
\hline
\end{tabular}

326 
$330 \quad$ Figure 1

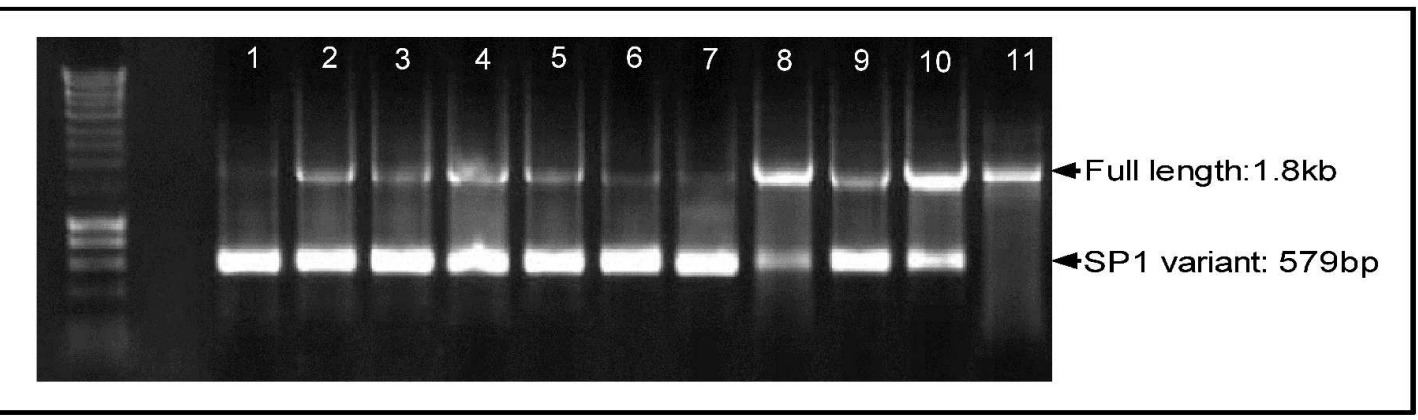

331

John Wiley \& Sons 